\title{
PARADIGMA BARU PERAN DOKTER DALAM PELAYANAN KEDOKTERAN FORENSIK
}

\author{
Rika Susanti \\ Bagian Forensik dan Medikolegal Fakultas Kedokteran Universitas Andalas \\ email : rikasusanti1976@yahoo.com
}

\begin{abstract}
Abstrak
Pelayanan kedokteran forensik semakin hari semakin luas, pada masa dahulu hanya sebatas pemeriksaan korban tindak pidana yang meninggal, sekarang sudah berkembng diantaranya pemeriksaan korban tindak pidana hidup, kekerasan dalam rumah tangga, child abuse and neglect, perselisihan pada perceraian, ragu ayah (dispute paternity) hingga ke pelanggaran hak asasi manusia. Bentuk ekspertise dari dokter forensik saat ini, tidak hanya terbatas pada hasil visum et repertum, akan tetapi juga pengeluaran surat keterangan kematian dan pengisian asuransi. Pelayanan kedokteran forensik sebagian besar dilakukan oleh dokter umum karena terbatasnya jumlah spesialis forensik. Peran dokter umum dalam pelayanan kedokteran forensik antara lain pemeriksaan korban tindak pidana hidup, pemeriksaan korban tindak pidana meninggal, sebagai saksi ahli, mengeluarkan surat keterangan kematian, penanganan kasus death on arrival, pengisian asuransi. Supaya tidak terjadi permasalahan terkait dengan pelayanan kedokteran forensik, diharapkan dokter menambah pengetahuan tentang kedokteran forensik dan aspek medikolegalnya.

Kata kunci : pelayanan kedokteran forensik-peran dokter umum-aspek medikolegal
\end{abstract}

\section{Abstract}

Forensic medicine service develop extensively from the dead victim examination to the various medical examination in the living victim, marriage violence,child abuse and neglect,divorce conflict,dispute paternity and violence in human rights. The expertise from forensic medicine specialist not only to publish visum et repertum but also to sign certificate of death and to admiss life insurance. Most of forensic medicine services performed by general practitioner because the lack of quantity of the forensic medicine specialist. The role of general practitioner in forensic medicine services are including the examination of the living and dead victims, expert witness in the court, publishing the certificate of the death, handling death on arrival patient, and admissing the insurance form. To avoid the problem, general practitioners should to improve their knowledge in forensic medicine services and its medicolegal aspect.

Keywords: forensic medical services-physician role-medicolegal aspects 


\section{PENDAHULUAN}

Pelayanan Kedokteran forensik adalah pelayanan kesehatan yang meliputi korban hidup dan korban mati yang berhubungan dengan tindak pidana. Pada zaman dulu orang lebih mengenal pelayanan forensik dengan pelayanan pathologi, yaitu pelayanan forensik untuk korban yang meninggal, ${ }^{(1)}$ sehingga tidak jarang seorang spesialis forensik identik dengan dokter mayat. Dengan berkembangnya ilmu dan teknologi yang disertai juga dengan perkembangan peradaban manusia, ilmu kedokteran forensik juga mengembangkan sayapnya keberbagai aspek selain dari pathologi forensik. Pada zaman dahulu ilmu kedokteran forensik juga identik dengan hanya memindahkan apa yang dilihat dari barang bukti/korban tanpa memberikan opini dari hasil pemeriksaan tersebut. Dokter hanya sebagai perantara, mencatat apa yang ditemukan kemudian menuangkan hasilnya dalam bentuk visum et repertum.

\section{RUANG LINGKUP PELAYANAN KEDOKTERAN FORENSIK}

Ruang lingkup ilmu kedokteran forensik berkembang dari waktu ke waktu. Pada mulanya hanya pada kematian korban kejahatan, kematian yang tidak terduga, mayat tidak dikenal hingga kejahatan korban yang masih hidup, bahkan pemeriksaan kerangka atau bagian dari tubuh manusia. ${ }^{1-3}$ Jenis perkaranyapun semakin meluas dari pembunuhan, penganiayaan, kejahatan seksual, kekerasan dalam rumah tangga, child abuseand neglect, perselisihan pada perceraian, ragu ayah (dispute paternity) hingga ke pelanggaran hak asasi manusia. ${ }^{(1)}$

Bentuk ekspertise dari dokter forensik saat ini, tidak hanya terbatas pada hasil visum et repertum, akan tetapi juga pengeluaran surat keterangan kematian dan pengisian asuransi. Dimana semua surat keterangan yang dikeluarkan tersebut mempunyai aspek medikolegal. ${ }^{(1,2,4)}$

Dalam penanganan medis korban yang masih hidup ataupun korban yang sudah meninggal mungkin saja akan melibatkan berbagai dokter dengan keahlian klinis yang tidak hanya dokter spesialis forensik, akan tetapi juga melibatkan dokter klinisi lain dan yang tidak kalah pentingnya adalah dokter umum yang ada di Instalasi Gawat Darurat. Siapapun dokter yang terlibat dalam penanganan korban tindak pidana, haruslah memakai ilmu kedokteran forensik, yang memegang prinsip pengumpulan barang bukti yang sebanyak - banyaknya. Dokter diharapkan memberikan keterangan tentang luka atau cedera yang dialami korban, penyebab luka, dan seberapa parah luka tersebut mempengaruhi kesehatan korban (derajat luka atau kwalifikasi luka). ${ }^{(5-7)}$

Adapun beberapa peran dari dokter yang sering terkait dengan pelayanan forensik adalah

1. Peran dokter dalam memeriksa korban tindak pidana hidup.

2. Peran dokter dalam pemeriksaan kasus kejahatan seksual.

3. Peran dokter dalam pemeriksaan jenazah.

4. Peran dokter dalam menangani kasus DOA.

5. Tatacara pengeluaran surat keterangan kematian.

6. Peran dokter sebagai saksi ahli.

\section{PERAN DOKTER DALAM MENANGANI KASUS TINDAK PIDANA HIDUP}

Beban/kewajiban untuk membuat visum et repertum atas seorang korban tindak pidana tidak bisa terlepas 
dari praktek sehari - hari. Dalam penyidikan untuk kepentingan peradilan menangani seorang korban yang diduga karena peristiwa tindak pidana, seorang penyidik berwenang mengajukan permintaan keterangan ahli kepada ahli kedokteran kehakiman atau dokter dan atau ahli lainnya. Seorang dokter sebagaimana pasal 179 KUHAP wajib memberikan keterangan yang sebaikbaiknya dan yang sebenarnya menurut pengetahuan di bidang keahliannya demi keadilan. ${ }^{(2,5-7,9)}$

Ketentuan tentang bantuan dokter untuk kepentingan peradilan didalam KUHAP tercantum didalam pasal 133 dan 179 dan 180. Seorang dokter jika dimintakan kepadanya untuk membutkan visum et repertum, maka secara hukum dokter wajib melakukan dan tidak ada alasan untuk menolak. ${ }^{(2,5,6,11)}$

Pasien yang termasuk kedalam lingkup pelayanan forensik klinik adalah pasien datang dengan surat permintaan visum, pasien korban tindak pidana penganiayaan, pasien korban kecelakaan lalu lintas, pasien dengan luka yang tidak jelas penyebabnya, pasien korban kekerasan seksual, pasien korban kecarunan/peracunan, pasien datang dengan surat permintaan visum. Jika pasien yang diperiksa termasuk ke dalam salah satu kriteria diatas, maka dokter mestinya sudah siap dengan pencatatan luka/cedera yang lengkap. Dokter baru akan mengelurkan hasil visum et repertum jika ada permintaan tertulis dari penyidik yaitu berupa surat permintaan visum (SPV). Pada praktek sehari - hari sering SPV datang belakangan. Untuk beberapa hal ini bisa dimaklumi, mungkin dengan alasan kondisi korban yang tidak memungkinkan untuk lapor ke polisi, kantor polisi yang jauh atau tidak mengerti tatacara pelaporan ke polisi. Sehingga yang sering terjadi adalah korban tindak pidana dengan surat permintaan visum yang datang terlambat, dokter kesulitan dalam membuatkan visum karena luka sudah di rawat dan tidak ingat lagi deskripsi luka pada saat pertama kali pasien datang, sehingga barang bukti menjadi tidak asli/ hilang. ${ }^{(2,7,12)}$

Beberapa hal yang akan dituangkan dalam visum et repertum korban hidup adalah $:^{(7,8)}$

1. Kronologis kejadian

2. Keadaan umum pasien

3. Luka/cedera yang ditemukan

4. Tindakan yang dilakukan terhadap pasien

5. Keadaan sewaktu dalam perawatan dan keadaan waktu pulang

6. Pada kesimpulan harus dijelaskan luka/cedera, kekerasan penyebab dan derajat/kwalifikasi luka.

Kesemua unsur diatas harus dituangkan ke dalam visum et repertum, yang dibuatkan dalam bentuk kalimat dan dalam bahasa Indonesia yang baku.

Deskripsi luka merupakan bagian yang cukup penting dalam visum et repertum. Tatacara penulisan luka adalah dengan urutan : regio, koordinat, jenis luka, deskripsi luka dan ukuran luka. $(2,7,8,13,14)$

Pada bagian kesimpulan, permasalahan sering terjadi dalam penentuan derajat luka. Derajat luka sangat berkaitan dengan jenis penganiayaan yang dilakukan dan berat ringannya ancaman hukuman terhadap pelaku. Pada umumnya penentuan derajat luka tidaklah sulit bagi dokter akan tetapi sampai saat ini belum ada standarisasi dari penentuan derajat luka, dokter hanya akan membuat derajat luka berdasarkan pemikiran mereka masing - masing, sehingga derajat luka bisa berbeda antara satu dokter dengan dokter yang lainnya. Hal ini tidak menjadi masalah sepanjang apa yang dibuat oleh dokter bisa dipertanggungjawabkan secara ilmiah. ${ }^{(7,13,14)}$ 
Prinsip utama yang harus diingat pekerjaan/jabatan dan pencahariannya" adalah bahwa dalam penentuan derajat dan jika derajat satu, dipakai kalimat luka kita melihat dari pandangan medis, yang ada di pasal 352 KUHP tidak melihat siapa korban, apa (penganiayaan ringan) yaitu: cedera/pekerjaannya. Guna memudahkan luka tersebut telah menimbulkan dalam penentuan derajat luka, bisa penyakit/halangan dalam menjalankan dengan cara sebagai berikut $:^{(13)}$

1. Jika ada luka, lihat apakah pekerjaan/jabatan dan pencahariannya memenuhi kriteria dalam pasal 90 KUHP, yaitu luka yang tidak dapat diharapkan sembuh dengan sempurna menimbulkan bahaya maut, terus menerus tidak dapat menjalankan pekerjaan, jabatan/pencaharian, hilangnya panca indra, kudung, lumpuh, gangguan daya pikir lebih 4 minggu, gugur/matinya kandungan. Jika memenuhi salah satu kriteria ini, maka luka adalah luka derajat tiga.

2. Jika luka tidak memenuhi pasal 90 KUHP, maka luka adalah derajat satu atau derajat dua. Untuk menentukan apakah derajat satu atau dua, perhatikan hal berikut : apakah luka mutlak perlu perawatan dokter, apakah akibat luka menyebabkan gangguan fungsi tubuh atau apakah jumlah luka banyak dan lokasinya apakah di tempat yang vital.

3. Jika memenuhi salah satu dari kriteria diatas, maka luka derajat dua, tetapi jika tidak memenuhi kriteria diatas maka luka derajat tiga.

untuk sementara waktu". ${ }^{(7,10,13)}$

Penandatanganan visum et repertum dilakukan oleh dokter yang memeriksa. Jika yang memeriksa korban hanya satu orang dokter, penandatanagan tidak menjadi masalah. Permasalahan akan muncul jika, korban ditangani oleh beberapa orang dokter, untuk kasus seperti ini tidak ada ketentuan tentang siapa yang seharusnya menandatangai, bisa dokter di IGD atau dokter yang merawat atau semua dokter yang terlibat. Ketentuan siapa yang harus menandatangani harus disepakati oleh rumah sakit masing masing. Untuk rumah sakit yang ada dokter spesialis forensik, biasanya pengeluaran visum et repertum, ditandatangan oleh dokter spesialis forensik jika dia yang memeriksa, akan tetapi jika bukan dokter forensik yang memeriksa, dan untuk meningkatkan nilai dari visum et repertum, maka dokter spesialis forensik ikut menandatangani sebagai yang mengetahui. $^{(2,12)}$

\section{PERAN DOKTER DALAM PEMERIKSAAN KORBAN KEJAHATAN SEKSUAL}

Setelah ditentukan derajat luka, selanjutnya kalimat yang akan ditulis didalam kesimpulan visum adalah: jika luka derajat tiga, kalimatnya sesuai dengan kriteria dalam pasal 90 KUHP yang cocok dengan luka/cedera yang ditemukan. Jika derajat dua, dipakai kalimat yang ada di Pasal 351 KUHP (penganiayaan) yaitu : "cedera/luka tersebut tidak menimbulkan penyakit/halangan dalam menjalankan

Kejahatan seksual yang diatur dalam undang-undang diantaranya adalah perkosaaan dan pencabulan. Pada kasus kejahatan seksual tugas dokter adalah mencari adanya tandatanda kekerasan dan adanya tanda-tanda persetubuhan. Pembuktian persetubuhan dilakukan dengan dua cara yaitu membuktikan adanya penetrasi (penis) kedalam vagina dan atau anus/oral dan membuktikan adanya ejakulasi atau 
adanya air mani didalam vagina/anus. Pembuktian ini memerlukan waktu yang sangat singkat antara kejadian dengan pemeriksaan/pengambilan barang bukti. ${ }^{(2,6,7,16)}$

Penetrasi penis ke dalam vagina dapat mengakibatkan robekan selaput dara atau bila dilakukan dengan kasar dapat merusak selaput lendir daerah vulva dan vagina ataupun laserasi, terutama daerah posterior fourchette. Robekan selaput dara akan bermakna jika masih baru, masih menunjukan adanya tanda kemerahan disekitar robekan. Pada beberapa korban ada yang memiliki selaput dara yang elastis sehingga tidak mudah robek. Pembuktian persetubuhan akan menghadapi kendala jika : korban dengan selaput dara yang sebelumnya telah robek lama, korban diperiksa sudah lama, korban yang memiliki selaput dara elastis, penetrasi yang tidak lengkap.

Pembuktian persetubuhan yang lain adalah dengan memeriksa cairan mani di dalam liang vagina korban. Dari pemeriksaan cairan mani akan diperiksa sel spermatozoa dan cairan mani sendiri. Namun kendala dalam pemeriksaan cairan mani adalah korban yang sebelumnya berhubungan seksual dengan orang lain, korban yang terlambat diperiksa, koitus interuptus, pelaku memakai kondom. ${ }^{(2,6,7,16)}$

Sehingga untuk pembuktian korban tindak pidana kejahatan seksual sangat diperlukan waktu yang singkat antara kejadian dan pemeriksaan, sehingga pengumpulan barang bukti bisa dikumpulkan dengan baik.

\section{PERAN DOKTER DALAM PEMERIKSAAN TINDAK PIDANA MATI KORBAN}

Pemeriksaan korban tindak pidana yang sudah meninggal, permintaan visum biasanya meliputi dua jenis pemeriksaan, yaitu pemeriksaan luar dan pemeriksaan dalam (otopsi). Dokter umum, sebenarnya tidak dibebankan untuk bisa melakukan pemeriksaan dalam, kalau masih memungkinkan untuk mendatangkan dokter spesialis forensik. Sedangkan untuk pemeriksaan luar jenazah merupakan kompetensi dokter umum untuk melakukannya. Tatacata pemeriksaan dan pencatatan dalam visum et repertum adalah memeriksa semua bagian tubuh jenazah dengan mencatat ke dalam formulir laporan obduksi. Prinsipnya tidak ada satu bagian tubuhpun yang luput dari pemeriksaan. Pada bagian kesimpulan dokter hanya menulis luka yang ditemukan, kekerasan penyebab dan sebab kematian. Cara mati bukan kewenangan dokter untuk menyatakan dalam visum et repertum. ${ }^{(2,6,7)}$

\section{PERAN DOKTER DALAM PENANGANAN KASUS DOA \\ DOA (Death on Arrival) adalah} merupakan keadaan dimana pasien atau korban ditemukan dalam keadaan sudah meninggal ditempat pelayanan. Biasanya kasus DOA masuk ke IGD suatu rumah sakit. Jika dokter menemukan kasus DOA, yang harus dilakukan adalah memeriksa pasien, melihat ada tanda kekerasan/ kemungkinan kasus tindak pidana dan sebelumnya sudah melakukan wawancara dengan pengantar mengenai kondisi terakhir jenazah dan kronologis kejadian. Jika ditemukan/dicurigai suatu tindak pidana atas kematian korban, maka dokter menganjurkan pengantar atau petugas rumah sakit untuk melapor ke polisi di wilayah tempat kejadian perkara. Selanjutnya jenazah ditahan di rumah sakit sampai penyidik memutuskan untuk tindakan forensik selanjutnya. Sedangkan jika dalam pemeriksaan dan wawancara dengan pengantar, disimpul- 
kan kematian wajar maka jenazah boleh dibawa pulang.

Untuk kasus DOA, prinsip utama yang harus diperhatikan dokter adalah memperkirakan cara kematian korban, apakah wajar atau tidak wajar guna penatalaksanaan selanjutnya.

\section{TATACARA PENGELUARAN SURAT KEMATIAN}

Surat keterangan kematian termasuk kedalam salah satu dari sekian banyak surat keterangan yang dikeluarkan oleh dokter. Surat keterangan dokter adalah keterangan tertulis yang dibuat oleh dokter untuk tujuan tertentu tentang kesehatan atau penyakit pasien, atas permintaan pasien atau atas permintaan pihak ketiga dengan persetujuan pasien atau atas perintah undang - undang. ${ }^{(2,6)}$

Surat keterangan kematian adalah surat yang menyatakan bahwa seseorang sudah meninggal. Surat keterangan kematian dibuat atas dasar pemeriksaan jenazah, minimal pemeriksaan luar. Dalam hal kematian berkaitan dengan tindak pidana tertentu, pastikan bahwa prosedur hukum telah dilakukan sebelum dikeluarkan surat keterangan kematian. Surat keterangan kematian tidak boleh atas seseorang yang mati diduga akibat suatu peristiwa pidana tanpa pemeriksaan kedokteran forenik terlebih dahulu. Pembuatan surat keterangan kematian harus dibuat secara hati-hati, mengingat aspek hukum yang luas, mulai dari urusan pensiun, administrasi sipil, warisan, santunan asuransi, hingga adanya kemugkinan pidana sebagai penyebab kematian. $^{(2)}$

Surat keterangan kematian minimal berisi, identitas korban, tanggal kematian, jenis pemeriksaan, sebab kematian. Pada rumah sakit yang sudah ada dokter spesialis forensik dan sistem pengeluaran jenazah satu pintu ke
Bagian forensik, maka surat keterangan kematian untuk seluruh mayat yang meninggal di rumah sakit dikeluarkan oleh dokter spesialis forensik. Jika kematian korban akibat suatu tindak pidana, maka surat keterangan kematian boleh dikeluarkan setelah dilakukan pemeriksaan forensik terhadap jenazah.

\section{PERAN DOKTER SEBAGAI SAKSI}

\section{AHLI}

Saksi ahli diperlukan pada proses pidana/peradilan untuk menjelaskan suatu perkara yang masih diragukan. Saksi ahli akan memberikan ketengan yang disebut keterangan ahli. Keterangan ahli adalah keterangan yang diberikan oleh seorang yang memiliki keahlian khusus tentang hal yang diperlukan untuk membuat terang suatu perkara pidana guna kepentingan pemeriksan (Pasal1 Butir 28 KUHAP).

Keterangan saksi berbeda dengan keterangan ahli, keterangan saksi diberikan berdasarkan pada hal yang dilihat, didengar' atau dialami sendiri sedangkan pendapat atau sangkaan yang diperoleh dari hasil pemeriksaan bukanlah merupakan keterangan saksi. Sedangkan keterangan ahli diberikan berdasarkan keilmuan/keahlian yang dimiliki. ${ }^{(2,6)}$

Keterangan ahli harus diberikan oleh seorang ahli yang memenuhi persyaratan kualifikasi dan berisikan keterangan yang berada dalam lingkup keahliannya (bukan keterangan yang bersifat awam). Ahli tidak perlu harus melihat, memeriksa atau mengalami sendiri, melainkan dapat pula hanya memberikan pendapatnya berdasarkan keilmuanya. $^{(2,11)}$

Saksi ahli haruslah bersikap jujur, obyektif, menyeluruh, ilmiah dan tidak memihak (imparsial). Saksi ahli tidak boleh melakukan misrepresentasi keahliannya maupun datanya, dalam arti bahwa data atau fakta yang akan 
digunakan sebagai dasar pembuatan pendapatnya harus secara tekhnis diketahui benar. Ia juga tetap harus mengikuti perkembangan keilmuannya dengan mengikuti pendidikan berkelanjutan. Dokter diharapkan untuk menghindari berbicara terlalu banyak, berbicara terlalu dini, dan berbicara dengan orang yang tidak berhak mendengar. ${ }^{(2,16)}$

Penampilan saksi ahli dipengadilanpun jangan melecehkan diri sendiri ataupun lawan bicara. Ia harus hadir tepat waktu, berpakaian rapi, sikap yang santun, menyiapkan data kasus, bersikap tegas dan yakin, mengutarakan sesuatu yang benar dan objektif serta menyeluruh.

\section{KEPUSTAKAAN}

1. Sampurna B. Dengan Kedokteran Forensik Klinik Menuju Cita-Cita Kemanusiaan Yang Adil dan Beradab, Pidato pada Upacara Pengukuhan Guru Besar Tetap dalam Ilmu Kedokteran Forensik dan Medikolegal. Fakultas Kedokteran Universitas Indonesia. Jakarta. 2007.

2. Sampurna B, Syamsu Z, Siswaja TD. Peranan Ilmu Forensik Dalam Penegakan Hukum. Ilmu Kedokteran Forensik Universitas Indonesia. Jakarta. 2008.

3. Sampurna B. Peran Forensik dalam Kasus Asuransi. Dalam: Indonesian Journal of Legal and Forensic Sciences, Vol 1(1). 2008. Hal 1720.

4. Stark MM. History and Development of Clinical Forensik Medicine. Dalam: Clinical Forensic Medicine: A Physician Guide
Edition $2^{\text {nd }}$. Human Press Inc. Totowa. 2011. Hal 20-9.

5. Idries AM, Sugiharto AF. Visum et Repertum, Pedoman Praktis Ilmu Kedokteran Forensik bagi Praktisi Hukum. Sagung Seto. Jakarta. 2009.

6. Budiyanto A, Widiatmaka W, Sudiono S. Ilmu Kedokteran Forensik. Bagian Ilmu Kedokteran Forensik dan Medikolegal Fakultas Kedokteran Universitas Indonesia. Jakarta. 1997.

7. Afandi D. Visum et Repertum Tata Laksana dan Teknik Pembuatan. UR Press. Pekanbaru. 2011.

8. Afandi D. Visum et Repertum Perlukaan : Aspek Medikolegal dan Penentuan Derajat Luka. Dalam: Majalah Kedokteran Indonesia, Vol 60, No.4. 2010. Hal 188-95.

9. Kitab Undang-Undang Hukum Acara Pidana.

10. Kitab Undang - Undang Hukum Pidana.

11. Kristanto E, Isries AM. Hak Undur Diri dalam Pemeriksaan di Sidang Pengadilan dalam Konteks Rahasia Kedokteran. Dalam : Penerapan Ilmu Kedokteran Forensik dalam Proses Penyidikan Edisi Revisi. Sangung Seto. Jakarta. 2008. Hal 252-6.

12. Atmadja DS. Aspek Medikolegal Pemeriksaan Korban Perlukaan dan Keracunan di Rumah Sakit. Dalam: Prosiding ilmiah Simposium Tatalaksana Visum et Repertum Korban Hidup pada Kasus Perlukaan dan Keracunan di 
Rumah Sakit. Rumah Sakit Mitra Kepala Gading. Jakarta. 2004.

13. Atmadja DS. Derajat Luka pada Kasus Perlukaan dan Keracunan. Dalam: Kursus Penulisan Visum Et Repertum pada Kasus Perlukaan. Dipresentasikan pada Simposium Visum et Repertum CME FKUI. Jakarta. 20 Maret 2008.

14. Herkutanto. Pemberlakuan Pedoman Pembuatan Visum et Repertum (VeR) Korban Hidup dan Trauma Related Injury Severity Score (TRISS) untuk
Meningkatkan Kualitas VeR. Dalam: Disertasi Program Studi Doktor Ilmu Kedokteran FKUI. Jakarta. 2005.

15. Dahlan S. Petunjuk Praktikum Pembuatan Visum et Repertum. Badan Penerbit Universitas Diponegoro. Semarang. 2003.

16. Meilia PDI. Prinsip Pemeriksaan dan Penatalaksanaan Korban Kekeraan Seksual, CDK-196, Vol.39, No.8. 2012. Hal 579-83. 
Lampiran 1: form VeR perlukaan

PROJUSTITIA

Padang, 20

\section{VISUM ET REPERTUM}

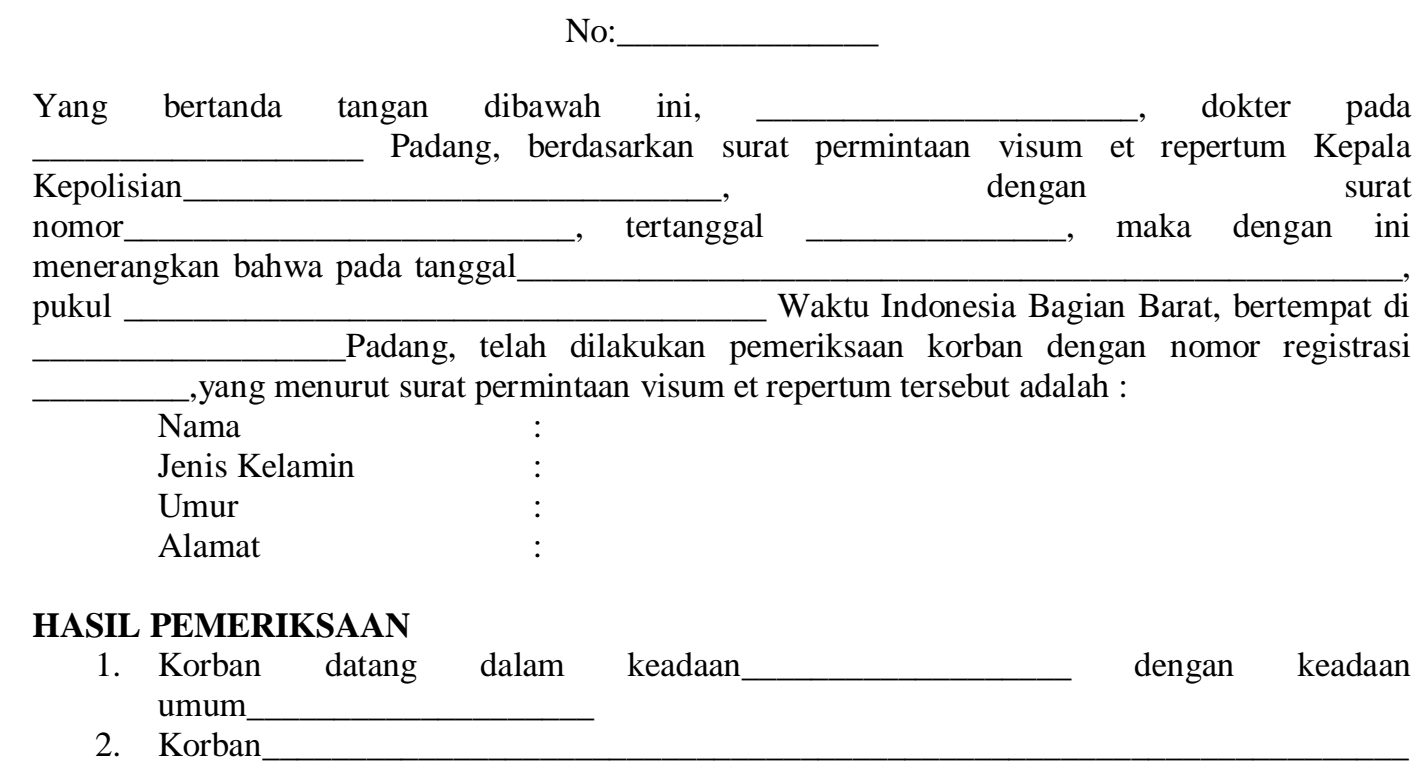

3. Pada korban ditemukan :

4. Terhadap korban dilakukan :

5. Korban dipulangkan/dirawat selama hari

\section{KESIMPULAN :}

Demikianlah visum et repertum ini dibuat dengan sebenarnya dengan menggunakan keilmuan yang sebaik-baiknya, mengingat sumpah sesuai dengan kitab undang-undang hukum acara pidana. 
Lampiran 2: form VeR kejahatan seksual

PRO JUSTITIA

Padang, 20

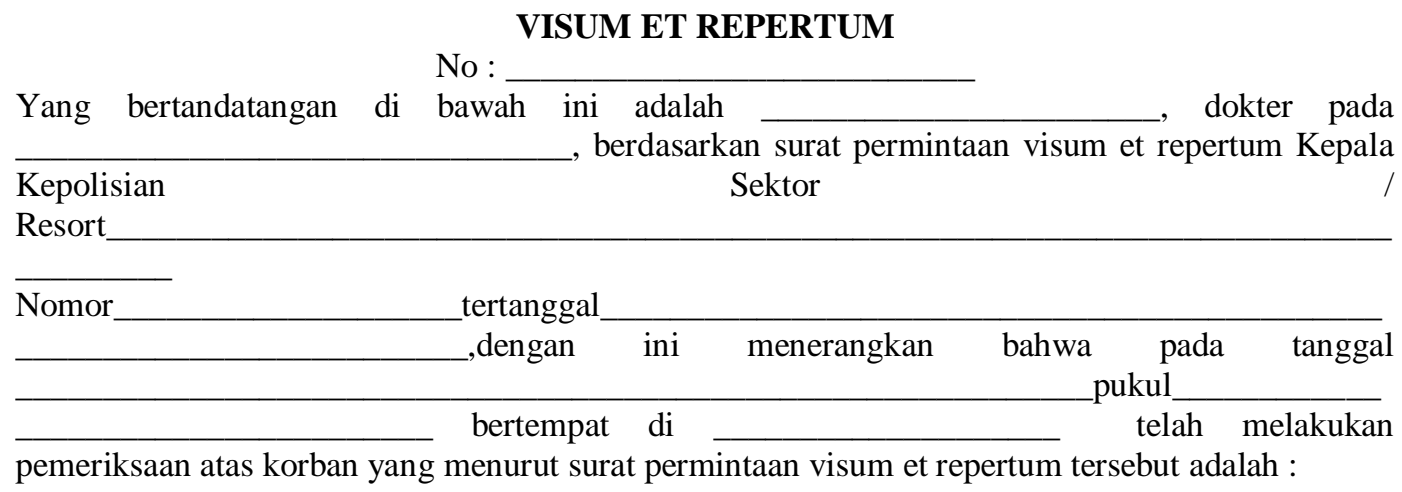

Nama

Tempat / tgl.lahir :

Alamat

HASIL PEMERIKSAAN :

1. Korban datang dalam keadaan dengan keadaan umum

Penampilan umum / sikap pakaian

2. Korban mengaku diperkosa / pada tanggal pukul

Pada saat itu ia mengalami (rincian peristiwa):

3. Riwayat haid : normal / ; riwayat perkembangan seksual : normal /

Persetubuhan terakhir tanggal : dengan / tanpa kondom

4. Pada tubuh korban ditemukan luka-luka sebagai berikut :

5. Pada pemeriksaan genitalia :

Bagian luar :

Selaput dara :

Bagian dalam :

KESIMPULAN

Demikianlah visum et repertum ini dibuat dengan sesungguhnya, berdasarkan keilmuan saya yang sebaik-baiknya dan dengan mengingat sumpah jabatan, serta sesuai dengan Undang-Undang No 8 tahun 1981 tentang Hukum Acara Pidana. 